\title{
Kent ormanı anlayışııla ODTÜ Ormanı manzarası için ekonomik değerin tahmin edilmesi
}

\author{
Dr. Güven KAYA ${ }^{* 1}$, Ercan ÖZYÜREK ${ }^{2}$ \\ 'İç Anadolu Ormancılık Araştırma Enstitüsü Müdürlüğü, ANKARA \\ ${ }^{2}$ Marmara Ormancılık Araştırma Enstitüsü Müdürlüğü, İSTANBUL \\ *iletişim yazarı/Corresponding author: guvenkaya@ogm.gov.tr, Geliş tarihi/Received:05.05.2015, Kabul tarihi/Accepted: 15.10.2015
}

\section{$\ddot{O} z$}

Son otuz yılda çevresel kaynaklar, mal ve hizmetlerin ekonomik değerinin belirlenmesine yönelik araştırmalar başta gelişmiş ülkelerde olmak üzere tüm dünyada yaygınlaşmıştır. Bu bağlamda sürdürülebilir orman kaynakları yönetimi ve etkin kaynak tahsisinde karşılaşılan bilgi eksikliğinin bir çözümü olarak, orman kaynaklarının, özellikle kent ormanlarının manzara güzelliğinin ekonomik değerinin tahminine yönelik birçok araştırma yapılmıştır. Türkiye'de bugüne kadar orman kaynaklarının sağladığı çevresel mal ve hizmetlerin ekonomik değerinin belirlenmesine yönelik birçok araştırma olmasına rağmen, orman, özellikle kent ormanı manzarasının ekonomik değerinin belirlenmesine yönelik bir araştırma bulunmamaktadır. Bu araştırmada Ankara şehir merkezinde bulunan Orta Doğu Teknik Üniversitesi (ODTÜ) Ormanı manzarasının ekonomik değerinin hedonik fiyatlandırma yöntemi ile tahmin edilmesi amaçlanmıştır. Çalışmada ODTÜ Ormanının manzara değeri, farklı nitelik göstergelerine göre, konut başına 15.535-23.315 TL, yıllık 8,06 ile 12,10 milyon TL, konut stoku için 101-151 milyon TL arasında tahmin edilmiştir. Sonuçlar, ODTÜ Ormanı manzarasının konutlar için arzu edilen bir nitelik olduğunu ve estetik faydalarının konut fiyatlarına yansıdığını göstermektedir.

Anahtar Kelimeler: Kent orman1, ODTÜ Orman1, hedonik fiyatlandırma, manzara, ekonomik değer

\section{Economic value estimation of scenic beauty of METU Forest in the context of urban forest}

\begin{abstract}
Scientific researches about economic valuation of environmental resources, goods and services have spread all over the world since 1980, especially in the developed countries. In this context, many studies on estimating economic values of scenic beauty of forest resources, especially of urban forests, have been realized due to lack of information involved in sustainable forest resource management and effective resource allocation. There was no published study to estimate economic value of scenic beauty of forests, especially urban forests in Turkey, while many environmental valuation researches on forest goods and services were reported. This study aimed to estimate economic values for scenic beauty of the Middle East Technical University (METU) Forest in city center of Ankara by using hedonic pricing method. The economic values of scenic beauty of the METU Forest are estimated as 15.535-23.315 TL per dwelling, 8-12 million TL per year and totally 101-151 million TL for target housing market. The results show that the scenic beauty of the METU Forest is an appreciated characteristic and its aesthetic benefits are capitalized in the property prices.
\end{abstract}

Keywords: Urban forest, METU Forest, hedonic pricing, scenic beauty, economic value

\section{Giriş}

Kent ormanları ve ormancılı̆̆ı, altmışlı yıllarda çok yönlü faydalanma ilkesi ile birlikte ABD ormancılığında gelişen olgulardır (Miller, 1997). Literatürde farklı tanımları olmakla birlikte, Konijnendijk (2003), bir alanın kent ormanı olabilmesi için kent içi veya yakın çevresinde $(50 \mathrm{~km}$ veya daha az uzaklıkta), kendini yenileyebilme, ziyaretçilerin yararlanabileceği uzaklıkta, en az 10 ha büyüklügüunde, kentin fiziksel yapısına, ekolojisine ve peyzajına, estetik ve işlevsel açıdan katkıda bulunma, yeşil dokuyu güçlendirme ve bütünlük sağlama özelliklerine sahip olması gerektiğini ifade etmektedir. Ülkelere ve kentlere göre kent ormanlarının farklı işlevleri öne çıkmaktadır. Ku- chelmeister (2000), kent ormanlarının işlevlerini ekolojik (kent iklimini iyileştirme ve hava kalitesini yükseltme, su kaynaklarının kullanımı, döngüsü ve korunmasını düzenleme, toprak koruma, çöplük ve atık depolama alanlarını ıslah etme, biyolojik çeşitliliği koruma), sosyal (görsel güzellikler sunma, doğa ve çevre eğitimi için ortam oluşturma, kent toplumunun sağlığına katkı sağlama, rekreasyon hizmetleri sağlama) ve ekonomik (yapacak ve yakacak odun hammaddesi sağlama, bitkisel besin maddeleri sağlama) olarak sınıflandırmaktadır.

Türkiye'de kent ormanları son yıllarda yaygınlaşmıştır. Mesire Yerleri Yönetmeliğinde (2013) kent (şehir) ormanları, "Ormanların öncelikle sağlık, spor, estetik, kültürel ve sosyal fonksiyonlarını 
halkın hizmetine sunmak, aynı zamanda yurdun güzelliğine katkı sağlamak, toplumun çeşitli spor ve dinlenme ihtiyaçlarını karşılamak, turistik hareketlere imkân vermek ve teknik ormancılık faaliyetleri ile flora ve faunanın da tanıtılarak, özellikle çocuklar ve gençlere orman sevgisi ve bilincinin aşılanması maksadıyla izcilik, doğa yürüyüşü, bisiklet, binicilik ve benzeri etkinlikler ile kır lokantası, kır kahvesi, kültür evleri, yöresel ürün sergi ve satış yeri, amfi tiyatro, çeşitli mini spor alanları ve diğer rekreasyonel yapı ve tesisleri ihtiva eden, il ve ilçelerde ayrılan yerler" olarak tanımlanmaktadır. Bu yasal çerçevede Orman Genel Müdürlüğü (OGM) tarafından Devlet ormanı mülkiyetinde 127 kent ormanı kurulmuştur (OGM, 2015). Bununla birlikte, ormanların çok yönlü faydaları dikkate alındığında kent ormanlarının, yasal tanımının ötesinde, kent havzalarının içi ve çevresinde bulunan ve kentlere Kuchelmeister (2000)'ın belirttiği faydaları sağlayan tüm ormanları kapsadığ 1 açıktır.

Kent ormanlarının manzarası ile sağladığı görsel güzellikler sunma işlevi, estetik işlev olarak da adlandırılmaktadır. Kentsel peyzajın önemli bir doğal elemanı olarak kent ormanı manzarası, insanlarda daha düşük stres seviyesi, duygusal ve ruhsal yenilenme olanağı, daha iyi komşuluk ilişkileri, agresif davranışlarda azalma ve sorunlarla baş etme yeteneğinde artış gibi sayısız sosyal ve psikolojik fayda sağlamaktadır (Zhu ve Zhang, 2008). Birçok araştırmada kanıtlanan bu pozitif ilişki kent toplumunun yaşam kalitesinin artmasını sağlamaktadır.

Kent ormanlarının estetik işlevi ile sağladığı hizmetlerin çoğu topluma dişsal fayda sağlayan, belirgin pazar fiyatı olmayan, geleneksel anlamda pazarı olmayan çevresel mallardır. Kamu malı niteliğinde olan bu hizmetlerin belirgin fiyatlarının olmaması; faydalarının mukayeseli büyüklüğünün kanıtlanamamasına ve değer bilgisi eksikliğine, dolayısıyla karar verme süreçlerinde iktisadi analizlerden dışlanmalarına yol açmaktadır. Estetik hizmetler gibi çevresel hizmetler için karşılaştırılabilir değer bilgisi ihtiyacı, sadece fayda-maliyet analizleri için değil, ayrıca sürdürülebilir orman kaynakları yönetimine yönelik gösterge geliştirme ve izleme çalışmaları, zarar-ziyan-tazminat hesapları, kaynak muhasebesi sistemleri ve orman değeri hesapları için de ortaya çıkmaktadır.

Son otuz yılda ormanların pazar dışı faydalarının ekonomik değerini belirlemeye yönelik artan çabalara paralel olarak, kent ormanları, parkları ve konut bahçeleri gibi kentsel yeşil alanların toplumun refahında yarattığı değişimi ölçmeye, diğer bir ifadeyle sağladığı hizmetlerin ekonomik değerini belirlemeye yönelik araştırmalar tüm dünyada yaygınlaşmıştır (Sander ve ark., 2010). Bu araştırmalarda önemli yöntemlerden biri olan hedonik fiyatlandırma yöntemi (HFY), konut fiyatları, kiraları veya emlak vergileri üzerindeki pozitif etki beklentisinden yola çıkarak kentsel yeşil alanların sağladığı manzara güzelliği ve rekreasyon hizmetlerinin ekonomik değerinin belirlenmesinde kullanılmaktadır.

Türkiye'de orman manzarası için gerçekleştirilmiş ekonomik değer belirleme araştırması olmamasından (Kaya, 2010) hareketle, bu araştırmada bir kent ormanının farklı manzara nitelikleri için HFY ile ekonomik değer tahminleri üretilmesi amaçlanmıştır. Araştırma alanı olarak, Ankara'da Ortadoğu Teknik Üniversitesi (ODTÜ) yerleşkesi içinde yer alan ODTÜ Ormanı seçilmiştir. ODTÜ Orman1, yasal olarak kent ormanı olmamakla birlikte, manzarasının etkilediği konut pazarının büyüklüğü, kent merkezinde yer alması ve kent toplumuna sağladığ 1 faydalar nedeniyle kent ormanı nitelikleri taşımaktadır ve bu çerçevede Konijnendijk (2003)'in belirttiği ölçütlere uygundur.

\subsection{Hedonik fiyatlandırma yöntemi}

HFY, her tür malın fiyat analizleri ve fiyatları üzerinde etkili faktörlerin araştırılmasında oldukça geniş bir kullanım alanına sahiptir. Çevresel değer belirleme alanında yöntemin ismi ve temel teorisi Sherwin Rosen tarafından 1974'te ortaya konmuş ve geliştirilmiştir. HFY, nitel değer teorisinden türetilmiştir ve temelinde, pazarı olan bir malın nitelikler demeti olarak görülebileceği, bu niteliklerden her birinin kendi örtük fiyatı olduğu ve bir kısmının pazarı olmadığı varsayımı geçerlidir (Rosen, 1974). Kendi başına pazarı olmayan mal olan bir nitelik için tercihlerin, pazarı olan heterojen, farklılaştırılmış veya bileşik bir malın pazar fiyatlarına yansıyacağı kabul edilir. HFY uygulamalarında genellikle konut pazarı kullanılır. Örneğin, daha iyi orman manzarasına sahip bir konutun daha yüksek bir fiyata satılacağ ${ }_{1}$ varsayılır. Bir yerleşim yerindeki konutlar arasında yeteri kadar orman manzaras1-konut fiyat1 varyasyonu varsa ve konut pazarından bu farklılaşmalara ilişkin yeteri kadar veri sağlanabilirse orman manzarasının örtük fiyatı bu ilişkiden yararlanarak türetilen hedonik fiyat (HF) fonksiyonu ile belirlenebilmektedir.

Bileşik bir mal olan $\mathrm{Z}, \underline{\mathrm{z}}=\mathrm{z}_{1}, \mathrm{z}_{2}, \mathrm{z}_{3}, \ldots \mathrm{z}_{\mathrm{n}}$ niteliklerinden oluşuyorsa, tam rekabet pazarında satıldığ varsayımı altında çok sayıda üretici ve tüketicinin etkileşimleri sonucu $\mathrm{Z}$ malı için $\mathrm{P}(\underline{\mathrm{z}})$ şeklinde bir denge fiyatı tarifesi oluşacaktır. Böylece HF fonksiyonu şu şekilde yazılabilir (Taylor, 2003):

$$
\mathrm{P}(\underline{\mathrm{z}})=f\left(\mathrm{z}_{1}, \mathrm{z}_{2}, \mathrm{z}_{3}, \ldots \mathrm{z}_{\mathrm{n}}\right)
$$

HFY uygulamaları genellikle değer belirleme probleminin saptanması, veri toplama, HF fonksiyonunun belirlenmesi ve ekonomik değerin (örtük 
fiyatın) hesaplanması olarak dört aşamalıdır. İlk aşamada, değeri belirlenecek çevresel malın örtük fiyatını içeren bileşik mal ve pazarı (vekil pazar), bileşik malın pazar fiyatını yansıtan ölçüt, çevresel malın ilgili bileşik mal ile etkileşiminin nasıl olduğu ve bu etkileşimi yansıtan HF fonksiyonunun genel formu belirlenir.

Konut fiyatını yansıtan ölçüt olarak konut satış fiyat1, kirası veya vergi değerlemeleri kullanılabilmektedir. Konut satış fiyatları, nitelik seviyelerinin farklı bileşimleri için dengede olduğu varsayılan konut pazarının gözlemlenen çıktısıdır. Konutun gelecekteki getirilerinin bugüne 1skonto edilmiş değerini gösterir; o nedenle uygun ölçüttür. Vergi değerlemeleri ise, pazar ortamından çok yasal düzenlemelere bağlıdır. Ayrıca satış fiyatları çevresel koşullarda gelecekte meydana gelebilecek değişimleri içerebilirken, konut kiraları sadece mevcut durumu yansitmaktadir (Taylor, 2003).

Çevresel malın konut fiyatlarını etkileyen nitelikleri (manzara kalitesi, uzaklığ 1 vb.) ve diğer konut nitelikleri belirlenerek oluşturulan HF fonksiyonunun gerektirdiği veriler kamu kurumları, emlak şirketleri, bankalar veya anketler aracılığıyla elde edilir. Sonra konut fiyatları ile konut nitelikleri arasındaki etkileşimin tipi belirlenir ve genellikle çoklu regresyon analizi ile HF fonksiyonu türetilir. HF analizlerinde doğrusal, yarı-logaritmik, tam logaritmik, üssel, üssel Box-Cox fonksiyon tipleri kullanılmaktadır. Konutların tüm nitelikleri için marjinal fiyatlar sabit olmayacağından HF fonksiyonunun doğrusal olmaması beklenir (Rosen, 1974; Hanley ve Spash, 1993; Taylor, 2003). O nedenle literatürde yarı logaritmik fonksiyon tipinin kullanımı yaygındır (Mendelsohn ve Markström, 1988).

Bir niteliğin örtük fiyatı, HF fonksiyonunun ilgili nitelik açısından kısmi türevi ile elde edilmektedir. Marjinal ödeme eğilimini yansıtan bu örtük fiyatlar, çevresel niteliğin mevcut stokunun konut fiyatları üzerindeki etkisi araştırılıyorsa ekonomik değerin uygun ölçüsüdür (Taylor, 2003).

\subsection{Literatür özeti}

HFY, günümüzde kent ormanları, diğer kentsel yeşil alanlar ve parklar ve diğer çevre kalitesi bileşenlerinin konut fiyatları ve kiraları üzerindeki etkisinden yola çıkarak çevresel mal ve hizmetlerin ekonomik değerinin tahmininde kullanılmaktadır. HFY araştırmalarında kentsel yeşil alanlarla ilgili nitelik olarak genellikle uzaklık (Hammer ve ark., 1974; Correll ve ark., 1978; More ve ark., 1988; Sielski, 2002; Netusil, 2005; Dehring ve Dunse, 2006), yaşlı ağaçların varlığı (Morales ve ark., 1983; Dombrow ve ark., 2000), ağaç sayısı (Anderson ve Cordell, 1988; Donovan ve Butry,
2010), yeşil alan varlığı (Tajima, 2003; Ahamada ve ark.,2008; Choumert ve ark., 2009) ve yeşil alanın uzaklığına ek olarak büyüklüğü veya yüzdesi (Morancho, 2003; Wang, 2005; Sander ve ark., 2010) gibi ölçütler kullanılmaktadır. Sonuçlar, genellikle konut fiyatları ile uzaklık arasında negatif, yeşil alan varlığı, büyüklüğü ve yüzdesi ile pozitif ilişki olduğunu göstermektedir. Bununla birlikte, Morancho (2003), HF fonksiyonlarında yeşil alana uzaklığın büyüklüğe göre daha anlamlı olduğunu bildirmektedir.

Kent ormanlarına odaklanan HFY araştırmalarında da benzer ölçütler kullanılmıştır. Finlandiya'da Joensuu kentinde rekreasyon alanına her 100 m'lik uzaklık artışının konut fiyatında 42 $\mathrm{FIM} / \mathrm{m}^{2}$ azalmaya yol açtığ 1 belirlenmiştir (Tyrvainen, 1997). Salo kentinde ise ormana uzaklikta 1 km'lik azalmanın konut fiyatında \%5,9 artış sağladığı, orman manzarasına sahip bir konuta alıcıların \%4,9 daha fazla ödeme yaptıkları hesaplanmıştır (Tyrvainen ve Miettinen, 2000).

Durham ve Orange kasabalarında (ABD, Kuzey Carolina), "yeşillik endeksi" kullanılarak orman örtüsünün konut fiyatları üzerinde pozitif etkisi görülürken ve kent ormanlarına uzaklık arttıkça konutların değerinin düştüğü, ancak kurum ormanına çok yakın konutlarda da fiyatların ciddi şekilde azaldığ 1 belirlenmiştir (Mansfield ve ark., 2005). Bir başka HFY araştırmasında (Melichar ve ark., 2009), Prag'da kent ormanına her 1 km'lik uzaklık artışı karşısında konut fiyatında \%1,61 azalma olduğu tahmin edilmiştir. ABD Michigan-Grand Rapids'de de doğrudan ormanla çevrili konut parsellerinin değerinin diğerlerinden \%19-35 daha yüksek olduğu belirlenmiştir (Thorsnes, 2002).

Türkiye'de HFY ile kentsel yeşil alanlar için İstanbul (Alkay, 2002), konutlara ait yeşil alanlar için İskenderun (Boyacıgil, 2003) ve Adana (Altunkasa ve Uslu, 2004) ve parklar ve oyun alanları için Erzurum'da (Yılmaz ve ark., 2008) gerçekleştirilen öncü ekonomik değer araştırmaları mevcuttur. Buca'da (İzmir) Yedi Göller rekreasyon alanı için manzara niteliğinin 1'den 7'ye yükselmesi karşılığında konut başına yaklaşık 75.000 TL'lik değer artışı olduğu belirlenmiştir (Abayhan ve Çubukçu, 2010). Ayrıca Ankara'da Botanik Parkının HF fonksiyonunda görüş (kapalı, yarı kapalı, yarı açık ve açık) ve parka uzaklık nitelikleri kullanılmış, parka uzaklıkta \%1'lik artış karşısında konut fiyatının \%0,072 azaldığ 1 belirlenmiştir (Tekel ve Akbarishahabi, 2013). Bu araştırmalar dışında kentsel yeşil alanların konut fiyatlarına etkisini araştıran, ancak ekonomik değer tahmini içermeyen HFY araştırmaları da (Eğdemir, 2001; Baldemir ve ark., 2008; Çetintahra ve Çubukçu, 2011) mevcuttur. 


\subsection{ODTÜ Ormanı}

1957 y1lında ODTÜ ve Türkiye Ormancılar Cemiyeti arasında yapılan protokol ile ODTÜ Atatürk Ormanı kurulması için başlayan çalıșmalarda başarı görülünce, 1960 yılında ODTÜ ve OGM işbirliğinde ODTÜ Ağaçlandırma Projesi ile ağaçlandırma seferberliği başlatılmıştır. Günümüze kadar yaklaşı 33 milyon fidan kullanılarak tesis edilen ve ODTÜ tüzel kişiliğgine ait olan ODTÜ Orman1 (Şekil 1), 3245'42'-3250'59'D boylamlar1 ve $39^{\circ} 48^{\prime} 40^{\prime \prime}-39^{\circ} 54^{\prime} 35^{\prime \prime} \mathrm{K}$ enlemleri arasında Ankara ili, Çankaya ve Gölbaşı ilçeleri sınırları dâhilinde yer almaktadır (ODTÜ, 2015).

Ankara Orman İşletme Müdürlüğü (AOİM) ODTÜ Ormanı Fonksiyonel Orman Amenajman Planına göre, plan ünitesinde 2875,9 ha ormanlık alan, 461,3 ha orman toprağ $1,711,2$ ha orman olmayan alan bulunmaktadır. 211 bölmeden oluşan ormanda ana ağaç türleri olan karaçam, sedir, sarıçam, badem ve az oranda kızılçam, dişbudak ve ahlatın meydana getirdiği topluluklar bulunmaktadır. Tür bileşimi açısından saf karaçam (750,7 ha), saf badem (198,2 ha), ibreli karışı (501,4 ha), ve ibreli yapraklı karışık $(1360,2)$ meşcereleri mevcuttur.

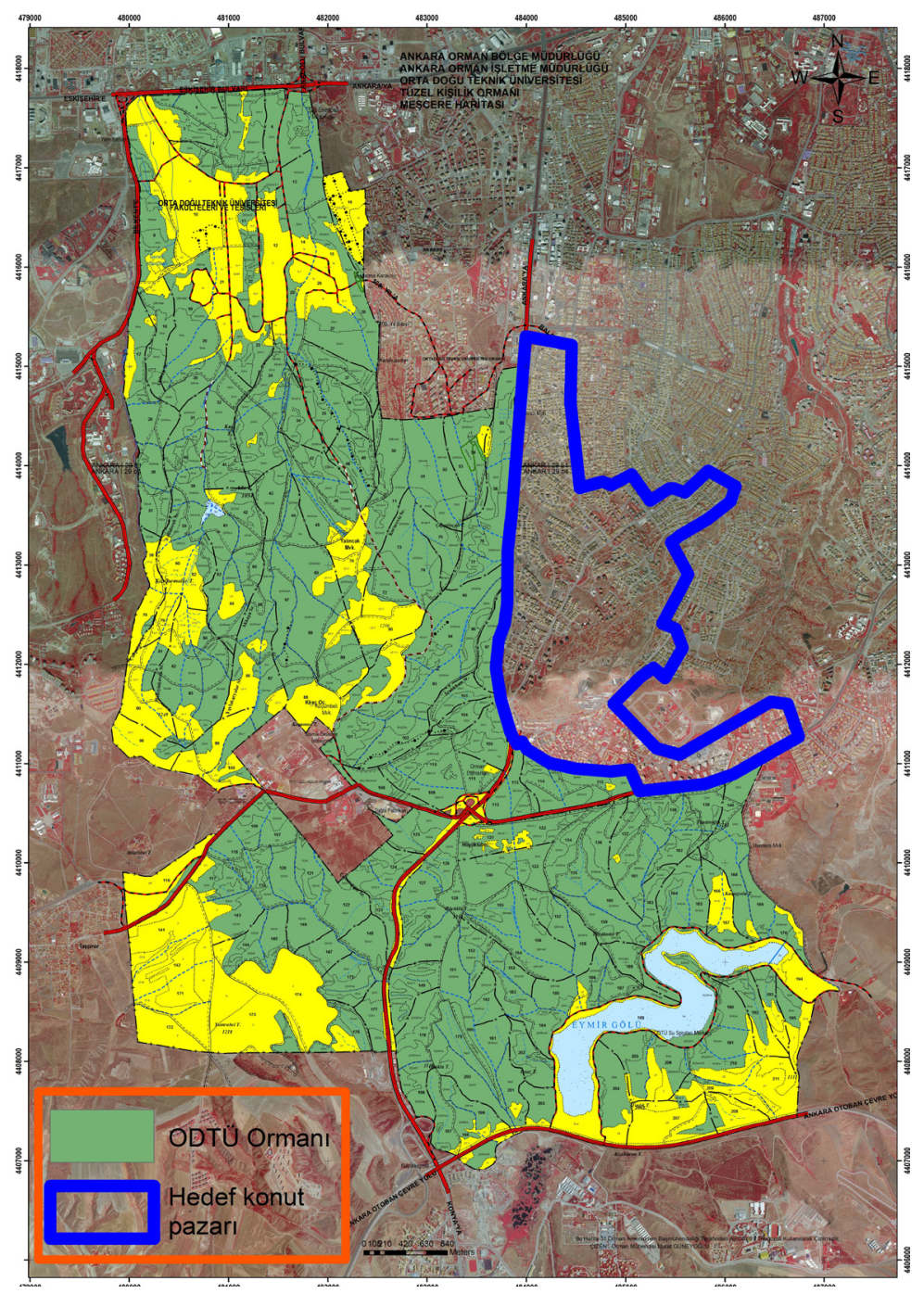

Șekil 1. ODTÜ Ormanı ve konut pazarı

Figure 1. The METU Forest and housing market

Amenajman Planında ekolojik fonksiyon için Arkeolojik Sit Alanı Karaçam (164,7 ha), Doğal Sit Alanı Karaçam (2367,3 ha) ve sosyal fonksiyon için Estetik Görünüm Karaçam (343,9 ha) olmak üzere ibreli-yapraklı karışık üç işletme sınıfı olarak planlanmıştır. 2859,1 hektarı verimli koru olan ormanın \%19'u 3 kapalı, \%23'ü 2 kapalı, \%58’i 1 kapalıdır; \%93'ü V. bonitette, \%82,5'i sirıklık ve direklik (b) gelişim çağındadır (AOİM, 2006).

ODTÜ Ormanındaki ağaç serveti $62.737 \mathrm{~m}^{3}$, yıllık artımı $4.469 \mathrm{~m}^{3}$ ve yıllık etası ortalama 113 
$\mathrm{m}^{3}$ 'tür. Toplam karbon birikimi ise 42.553 ton olarak hesaplanmıştır (AOİM, 2006). Bu stok değer, yıllık artımı/ağaç serveti oranı ile çarpıld1ğ1nda y1llık karbon birikiminin 3.031 ton olduğu görülmektedir. İyimser bir yaklaşımla karbonun fiyatı 10 \$/ton kabul edilirse, 2013 yılı Haziran ayı ABD Doları ortalama kuru $(1 \$=1,90 \mathrm{TL}$, TC Merkez Bankası, 2013a) kullanıldığında ODTÜ Ormanının karbon tutma hizmetinin değeri yıllık 20 TL/ha olarak hesaplanmaktadır. OGM 2012 yılı satış gelirleri (OGM, 2015) esas alınırsa, alanın odun hammaddesi üretimi gelirleri, dolay1sıyla gayrisafi değeri yıllık 184 TL/ha olabilir.

\section{Materyal ve Yöntem}

\subsection{Materyal}

HFY'nin gerektirdiği verilerin toplanması için tasarlanan anket formu, emlak şirketlerinin web siteleri, amenajman planı, mekânsal verilerin elde edilmesi ve işlenmesi için haritalar (Ankara İ29-b1 ve b4 paftalar1), uydu görüntüleri, fotoğraflar, hedef konut pazarına ilişkin temel istatistik veriler çalışmanın materyalini oluşturmuştur. Alan ve çevresinin ortofoto haritaları OGM Bilgi Sistemleri Daire Başkanlığı, diğer haritalar Amenajman Planından, uydu görüntüleri ise Google Earth programı ile temin edilmiştir.

\subsection{Yöntem}

Araştırmada HFY'nin temelinde yatan konutların her biri ayrı bir mal olan nitelikler demeti olarak kabul edildiği, bu niteliklerden bazılarının pazar fiyatı mevcutken, pazar fiyatı olmayan orman manzarası niteliklerinin konut fiyatına etkisi olduğu varsayımından hareket edilmiştir $\left(\mathrm{H}_{1}\right)$.

\subsubsection{Hedef pazarın belirlenmesi}

Bu araştırmada bir kent ormanı olarak ODTÜ Ormanının manzarasının ekonomik değerinin HFY ile belirlenmesi amacıyla konut pazarı vekil olarak seçilmiştir. ODTÜ Ormanı, Ankara ili Çankaya, Gölbaşı ve Yenimahalle ilçelerinden görülmekle birlikte, konut pazarının sınırlandırılmasını gerektiren birçok kısıtlama mevcuttur:

- Manzaranın etkisinin uzaklıkla ters orantılı olduğuna ve sınırlı olduğuna yönelik literatür bilgisi,

- Orman manzarasına sahip bazı mahallelerde üniversite yerleşkesi, kamu binaları ve özel işyerleri ve ticaret merkezlerinin yoğunlukta olmas1,

- Çevredeki birçok mahallenin kot farkları nedeniyle ODTÜ Ormanı manzarasına sahip olmaması veya varyasyon sağlayamayacak kadar çok küçük bir kısmının ODTÜ Ormanı manzarasına sahip olması,

- Çalışma zamanında bazı mahallelerde konut fiyatlarında yaşanan spekülatif fiyat artışları ve

- Bazı mahallelerde pazar bölümlendirmesi sorununa yol açabilecek dubleks ve tripleks konutların yoğunlukta olması.

Yukarıdaki kısıtlamalar dikkate alınarak ODTÜ Ormanının Kuzey bölümünün doğusunda yer alan ve Güney bölümünün kuzeyinde yer alan, Şekil 1'de mavi çizgi ile sınırları belirtilen ve Çankaya ilçesindeki 11 mahalleyi içeren alan hedef konut pazarı olarak belirlenmiştir. Çalışma alanı sınırlandırılırken 1994 tarihli Ankara İ29b1 ve İ29b4 Memleket haritaları üzerinde eşyükselti eğrileri ve kot farklarından yararlanılmış, ayrıca ODTÜ Ormanından çekilen fotoğraflarda mahalle bazında ODTÜ Ormanı manzarasına sahip konut oranının \%10'dan fazla olması bir kısıt olarak alınmıştır.

\subsubsection{Hedonik fiyat modeli ve veri gereksinimi}

Araştırmada bileşik mal olarak konutlar, bileşik mal fiyatı olarak konut niteliklerinin örtük fiyatlarını içeren konut satış fiyatları kullanılmıștır. Kurulan HF modelinde konut satış fiyatlarının konutların iç yapısal nitelikleri, dış yapısal nitelikleri, ulaşılabilirlik, komşuluk ve orman manzarasına ilişsin nitel ve nicel ölçütleri de içeren nitelik gruplarının bir fonksiyonu olduğu kabul edilmiştir:

- Konut konumu: Mahallesi ve hakim bak1s1

- İç yapısal nitelikleri: Konut tipi, oda sayısı, yaş1, alanı, katı, sahiplik ve tapu tipi, mutfak, salon, diğer odalar, balkon, teras, WC ve banyo gibi tüm bölümleri, zemin, duvar, pencere ve kapı donatılarının tipi ve kalitesi, 1sıtma ve yakıt tipi

- Diş yapısal nitelikleri: Konutun bulunduğu yapıda (apartman, müstakil bina) kat sayısı, daire say1s1, boş daire sayısı, kattaki daire sayıs1, site/toplu konut niteliği, yapı tipi, ortak kullanılan donatı tipleri, kalitesi ve olanakları

- Komşuluk nitelikleri: Gelir ve eğitim seviyesi, suç oranı, işsizlik oranı, trafik sorunu, çevresel sorunları (hava ve gürültü kirliliği ve at1k sorunu)

- Ulaşılabilirlik nitelikleri: Şehir merkezine, ulaşım, eğitim, sağlık, iş ve alışveriş olanaklarına yakınlık

- Manzara nitelikleri: Konut manzarasının ögeleri, ODTÜ Ormanı ve diğer yeşil alan manzaralarının fiziksel niteliği, ODTÜ Ormanı manzarasının kalitesi ve en önemli manzara ögesi, ODTÜ Ormanına uzaklık ve kategorileri, ODTÜ Ormanı manzarasında kapsanan 
orman alanı (genel, meşcere çağı, ağaç türleri ve karışımı)

\subsection{3. Örnekleme}

Minimum örneklem büyüklüğü, ana kütle bilindiğinde olayın gerçekleşme olasılığına göre örneklem büyüklüğünü veren formülle hesaplanmıştır:

$$
\mathrm{n}=\left(\mathrm{N} \cdot \mathrm{p} \cdot \mathrm{q} \cdot \mathrm{Z}^{2}\right) /\left[(\mathrm{N}-1) \cdot \mathrm{d}^{2}+\text { p.q. } \mathrm{Z}^{2}\right]
$$

Formülde n, örnek büyüklüğünü; $\mathrm{N}$, ana kütle büyüklüğünü; $p$, ölçülen özelliğin ana kütle içinde bulunma olasılığını; q, ölçülmek istenen özelliğin ana kütle içerisinde bulunmaması olasılığını; Z, \%95 güven düzeyinde $Z$ test değerini $(1,96)$; $d$, hata payını $(0,05)$ ifade etmektedir.

Çalışmanın ana kütlesi (N), hedef konut pazarında Eylül 2011-Haziran 2013 ayları arasında yaklaşık 2 yıl süren veri toplama sürecinde (t) kendisi kullanmak üzere konut satın alan alıcılardır. Türkiye İstatistik Kurumu (TÜİK) verilerine göre, Ankara'da 2011 yılında 117.908 konut satış1 (s) gerçekleşmiştir (TUIKK, 2013a). Ankara ilinde ikamet ettiği konuta sahip olanların oranı (r), \%60,9'dur (TÜİK, 2013b). Bununla birlikte 2011 yılı nüfus verilerine göre (TÜİK, 2011), Ankara ilinin nüfusu 4.890.893, ortalama hane halkı büyüklüğü 3,30, dolayısıyla hane halkı sayısı $\left(\mathrm{HS}_{\mathrm{ANK}}\right) 1.482 .089$ 'dur. Çankaya ilçesi mahallelerine ait hane halkı sayısı $\left(\mathrm{HS}_{\mathrm{KP}}\right)$ verilerine göre ise hedef konut pazarında 24.170 hane halkı ikamet etmektedir (TÜİK, 2013c). Bu sayı, hedef konut pazarındaki konut sayısı olarak kabul edilmiştir. Buna göre ana kütle büyüklüğü şu şekilde hesaplanmıştır:

$$
\mathrm{N}=\mathrm{s} . \mathrm{t} \cdot\left(\mathrm{HS}_{\mathrm{KP}} / \mathrm{HS}_{\mathrm{ANK}}\right) \cdot \mathrm{r} \cong 2.342
$$

ODTÜ Ormanından hedef konut pazarının görüntüleri kullanılarak ODTÜ Ormanı manzarasına sahip herhangi bir bölümü (oda, balkon, teras) görünen konutların sayısı, 6.480 olarak sayılmıştır. Hedef konut pazarında ODTÜ Ormanı manzaras1na sahip konutların oran $1 \% 26,8$ olduğu için p değeri 0,268 ve q değeri 0,732 olarak alınmıştır. Buna göre örneklem büyüklüğü (n), 267 olarak hesaplanmıştır.

Hedef konut pazarında mahallelerin yapılaşma ve ODTÜ Ormanı manzarasına sahip konut oranlarının farklı olması ve uzaklığın etkisi dikkate alınarak mekânsal korelasyondan sakınmak için tabakalı örnekleme yöntemi kullanılmıştır. Ortofoto haritalarda ODTÜ Ormanı-hedef konut pazarı sınırına paralel $250 \mathrm{~m}$ genişliğinde şeritlerde mahalle x uzaklık tabakaları oluşturulmuştur. ODTÜ Ormanı manzarasına sahip yapı oranı esas alınarak örneklem büyüklüğü tabakalara dağıtılmıştır. Her bir tabaka içinde konutların seçiminde rasgele örnekleme yöntemi kullanılmıştır. Mekânsal korelas- yondan sakınmak için ayrıca aynı apartman veya sitede hâkim bakı ve kat nitelikleri açısından benzer olan konutların seçilmemesine dikkat edilmiştir.

\subsection{Veri toplama}

Konut satış ve mülkiyet bilgileri ile modeldeki konut niteliklerine ilișkin bilgilerin büyük bölümünün elde edilmesi için bilgi toplama formu niteliğinde açık ve kapalı uçlu sorulardan oluşan bir anket formu tasarlanmıştır. $\mathrm{Bu}$ formda manzara nitelikleri dışındaki soruların emlak firmaları yetkilileri ve konut alıcıları ile kişisel görüşmeler ve emlak firmalarının web sitelerinden elde edilen bilgiler kullanılarak cevaplanması öngörülmüştür. Anket formunda konutların manzara nitelikleriyle ilgili beş soru (konut manzarasının ögeleri, ODTÜ Ormanı ve diğer yeşil alan manzaralarının fiziksel niteliği, ODTÜ Ormanı manzarasının kalitesi ve en önemli manzara ögesi) yer almıştır.

HF fonksiyonunda konut fiyatlarının alıcılar için veri olduğu (rekabetçi piyasa) koşulu geçerlidir. Yeşil alan manzaralarının fiziksel niteliğine ilişkin sorular, bu varsayıma uygun olarak hazırlanmıştır. $\mathrm{Bu}$ sorularda beşli cevap ölçeği (Benson ve ark., 2000; Pearson, 2002; Lothian, 2010) kullanılmıştır. Ölçekte "Yok" seçeneği, ilgili ögenin manzarada olmadığı; "Oldukça sinırlı görüntü", konutun en iyi görüşe sahip bir noktasında ögenin görüş alanının yatay olarak \%30'undan azını kapsadığı, kalan alanın engelli olduğu; "Sınırlı görüntü", konut manzarasında ilgili ögenin yatay olarak \%30-\%60 arasını kapsadığ1; "Parçalı görüntü", ilgili ögenin konut manzarasının \%60'dan fazlasını kapsad1ğ1, fakat arada yapay veya doğal engeller olduğu; “Tam/açık görüntü” ise \%60'in üzerinde ve ilgili ögenin görülmesinde hiçbir engel olmadığı anlamına gelmektedir. Bu ölçeğin, emlak firmalarının web sitelerinden elde edilen fotoğraflar, konutların çevresinden ve ODTÜ Ormanından karşılıklı fotoğraflar, doğrudan gözlem ve uydu görüntüleri kullanılarak araştırmacılar tarafindan cevaplanması öngörülmüştür.

ODTÜ Ormanı manzarasının kalitesinin sorgulandığı soruda ise, literatürden de (Taylor ve ark., 1987) faydalanılarak altılı ölçek (çok yüksek, yüksek, orta, düşük, çok düşük, yok) yer almıştır. Bu soruda tam rekabet koșullarının dıșında, konut alıcılarının bireysel algıları önemsenmiştir.

Hedef konut pazarında 30 konut alıcısı ile test edilerek nihai şekli verilen anket formu ile anket çalışması, Eylül 2011-Haziran 2013 ayları arasında satışı yapılan ve alıcının ikamet ettiği toplam 303 konut için tamamlanmıştır. Araştırma örnekleminde yer alan konutların konumları Şekil 2'de verilmiştir. 
Konutlardan orman manzarasının görüntüleri ve ODTÜ Ormanından hedef konut pazarının görüntüleri kullanılarak her bir konut manzarasında yer alan orman sınırları ODTÜ Ormanı meşcere tipleri haritas1, topoğrafik ve ortofoto haritalara işaretlenmiştir. $\mathrm{Bu}$ haritalar üzerinde konutların uzaklık ve manzara alanı nitelikleri, ArcGIS yazılımı ile ölçülmüştür. $\mathrm{Bu}$ veri kullanılarak konut manzarasındaki ODTÜ Ormanı meşcere tipleri için ağaç türleri, gelişme çağları ve kapalılıkları ile ilgili çeşitli alansal değişkenler de tasarlanmış ve veri setleri hazırlanmıştır.
Konutların satış zamanı 22 ayı kapsadığından Ankara ili aylık konut fiyat endeksi (TC Merkez Bankası, 2013b) yardımıyla konut satış fiyatlarının Haziran 2013'teki değeri hesaplanarak kullanılmıştır.

\section{4. İstatistik analizler}

Anket ve bilgi toplama çalışması tamamlanan 303 konuttan 7'si verilerin uç değerler içermesi ve bilgi eksikliği nedeniyle örneklemden çıkarılmış ve hedonik analizler 296 gözlemle gerçekleş-

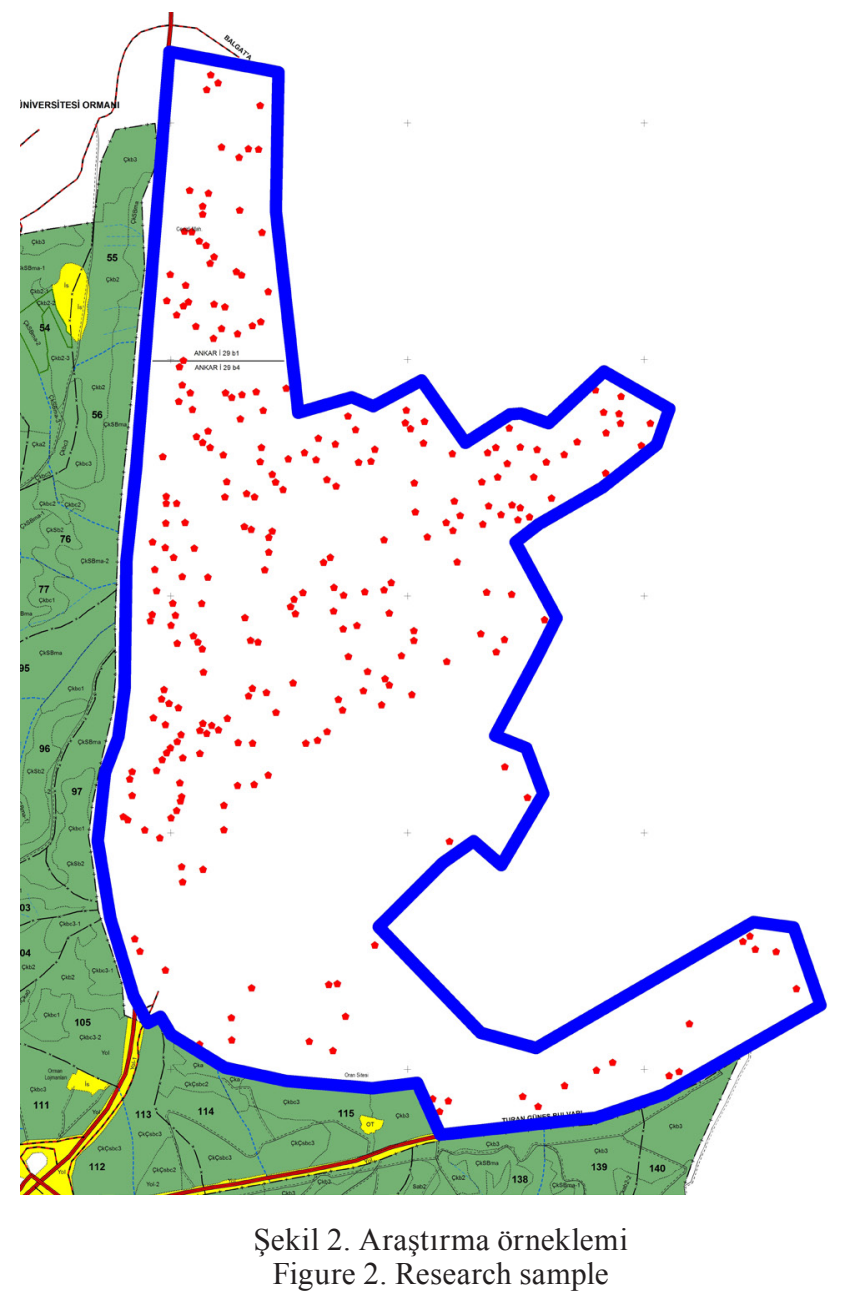

tirilmiştir. Anket formlarından elde edilen verilerin işlenmesi, nitel verilerin sayısallaştırılması ve değişkenlerin türetilmesinde MS Office Excel yazılımı, HF fonksiyonlarının türetilmesinde çoklu korelasyon ve çoklu regresyon analizleri için SPSS 15.0 yazılımı kullanılmıştır.

$\mathrm{Bu}$ araştırmada yarı logaritmik fonksiyon tipi ile orman manzarasının farklı nitelikleri için değişkenler kullanılarak farklı HF fonksiyonları türetilmiştir:

$\ln [\mathrm{P}(\underline{\mathrm{z}})]=\alpha_{0}+\sum \beta_{\mathrm{i}}$ KONUM $_{\mathrm{i}}+\sum \beta_{\mathrm{j}}$ YAPISAL $_{\mathrm{j}}$ $+\sum \beta_{\mathrm{k}}$ KOMŞULUK $_{\mathrm{k}}+\sum \beta_{\mathrm{l}}$ ULAŞILABILIRLIK $_{\mathrm{l}}$ $+\sum \beta_{\mathrm{M}}$ MANZARA $_{\mathrm{M}}+\varepsilon$
Yukarıdaki fonksiyonda yer alan ODTÜ Ormanı manzarası nitelikleri için örtük fiyatlar (marjinal ödeme eğilimleri), dolayısıyla ekonomik değer tahminleri şu şekilde hesaplanmıştır:

\section{Bulgular}

$$
\partial \mathrm{P} / \partial \mathrm{z}_{\mathrm{i}}=\beta_{\mathrm{m}} \cdot \mathrm{P}
$$

Örneklemde yer alan 296 konutun 198'i ODTÜ Ormanı manzarasına sahiptir. ODTÜ Ormanı manzarasının fiziksel boyutu incelendiğinde konutların \%26,0'sı tam/açık görüntüsüne, \%10,5'i parçalı görüntüsüne, $\% 12,5^{\prime}$ 'i sinırlı görüntüsüne, $\% 17,9$ ’u 
oldukça sınırlı görüntüsüne sahip olduğu belirlenmiştir. Konutların ODTÜ Ormanı manzara kalitesi ise, \%14,5'inin çok yüksek, \%16,6'sının yüksek, \%14,9'unun düşük ve \%13,5'inin çok düşük olarak nitelendirilmiştir. Konutların \%33,1'i ODTÜ Ormanı manzarasına sahip değilken, alıcıların \%35,8'i en önemli manzara ögesi olarak ODTÜ Ormanını göstermiştir. Diğer yandan, örneklemdeki konutlar, 2875,9 hektar büyüklüğündeki ODTÜ Ormanının 1133,64 hektarlık bölümünün manzarasına sahiptir. Orman Amenajman Planına göre, bu alanın sadece 37,41 hektarı $(\% 3,3)$ estetik işleve tahsis edilmiştir.

ODTÜ Ormanı manzarasının niteliklerine göre türetilen farklı değişkenlerle altı HF fonksiyonu türetilmiştir. HF fonksiyonlarında yer alan konut niteliklerine ait değişkenlerin tanımları, betimleyici istatistikleri ve fonksiyonda beklenen işaretleri Tablo 1'de verilmiştir.

Konutların manzara ve diğer nitelikleriyle ilgili türetilen birçok değişken, bireysel olarak konut fiyatlarıyla anlamlı ilişkisi olmasına rağmen, otokorelasyon problemi nedeniyle çoklu regresyon analizi denemelerinde anlamlı olarak HF fonksiyonlarında yer alamamıştır. $\mathrm{Bu}$ sorunun nedenleri, bazı niteliklerin konutlarda birlikte veya yaygın olarak bulunmalarıdır.

Tablo 1. Değişken tanımları ve betimleyici istatistikler Table 1. Definitions and descriptive statistics of variables

\begin{tabular}{|c|c|c|c|c|c|c|}
\hline \multirow{2}{*}{ Değişkenler } & \multirow{2}{*}{ Tanım } & \multicolumn{2}{|c|}{ Tüm örneklem } & \multicolumn{2}{|c|}{ Orman Man. Konutlar } & \multirow{2}{*}{$+/-$} \\
\hline & & Ort. & St. Sp. & Ort. & St. Sp. & \\
\hline STFYTE & Endeksli konut satış fiyatı (TL) & 288.877 & 184.287 & 327.136 & 205.420 & \\
\hline ALAN & Konutun alanı $\left(\mathrm{m}^{2}\right)$ & 162,57 & 60,06 & 174,71 & 64,98 & + \\
\hline ODASY & Oda say1s1 & 3,53 & 0,99 & 3,68 & 1,02 & + \\
\hline KATOR & Konut katı/yapıdaki kat sayısı & 0,49 & 0,42 & 0,58 & 0,37 & + \\
\hline SİTE & Site içinde ise 1 , değilse 0 & 0,30 & 0,46 & 0,34 & 0,47 & + \\
\hline MUTF1 & Ankastre mutfak dolabı varlığı $(1,0)$ & 0,31 & 0,46 & 0,39 & 0,49 & + \\
\hline MUTF2 & Mutfakta beyaz eşya varlığ $(1,0)$ & 0,06 & 0,25 & 0,09 & 0,28 & + \\
\hline BANYO & Ebeveyn banyosu varlığ $(1,0)$ & 0,60 & 0,49 & 0,69 & 0,46 & + \\
\hline GDOLAP & Gömme dolap varlığ $1(1,0)$ & 0,36 & 0,48 & 0,41 & 0,49 & + \\
\hline BALKON & Kapalı balkon varlığ $1(1,0)$ & 0,37 & 0,48 & 0,35 & 0,48 & + \\
\hline DEKOR & Konutta özel dekorasyon varlığ $1(1,0)$ & 0,02 & 0,14 & 0,01 & 0,10 & + \\
\hline PKAPI & Panel kapı varlığı $(1,0)$ & 0,68 & 0,47 & 0,70 & 0,46 & + \\
\hline SZEMIN & Seramik zemin varlığı $(1,0)$ & 0,82 & 0,38 & 0,83 & 0,38 & + \\
\hline KONMER & Yapıda kondisyon merkezi $(1,0)$ & 0,09 & 0,29 & 0,14 & 0,34 & + \\
\hline OTPARK & Yapıda kapalı otopark varlığ $(1,0)$ & 0,32 & 0,47 & 0,43 & 0,50 & + \\
\hline ORAN & Or-an mahallesinde ise 1 , değilse 0 & 0,08 & 0,27 & 0,12 & 0,32 & + \\
\hline DOGU & Hâkim bakı Doğu ise 1, değilse 0 & 0,11 & 0,32 & 0,06 & 0,24 & - \\
\hline CADDE & Ana cadde kenarında ise 1 , değilse 0 & 0,18 & 0,39 & 0,19 & 0,39 & + \\
\hline MNPARK & Mahalle parkı manzarası varlığ $1(1,0)$ & 0,17 & 0,38 & 0,21 & 0,41 & + \\
\hline MNGÖL & Göl manzarası varlığı $(1,0)$ & 0,04 & 0,20 & 0,06 & 0,24 & + \\
\hline MNORM & ODTÜ Ormanı manzarası varlığ $1(1,0)$ & 0,67 & 0,47 & 1,00 & 0,00 & + \\
\hline ORGÖR & $\begin{array}{l}\text { Orman manzarası tam/açık görüntü (4), parçalı gö- } \\
\text { rüntü (3), sinırlı görüntü (2), oldukça sinırlı görüntü } \\
(1), \text { yok (0) }\end{array}$ & 1,78 & 1,62 & 2,67 & 1,24 & + \\
\hline ORKLT & $\begin{array}{l}\text { Orman manzarası kalitesi çok yüksek (5), yüksek } \\
\text { (4), orta (3), düşük (2), çok düşük (1), yok (0) }\end{array}$ & 2,12 & 1,89 & 3,17 & 1,42 & + \\
\hline ORUZAK & ODTÜ Ormanının en yakın sınırına uzaklık (m) & 644,36 & 528,82 & 531,01 & 482,74 & - \\
\hline ORALAN & Konut manzarasında ODTÜ Ormanı alanı (ha) & 38,62 & 111,74 & 57,74 & 132,62 & + \\
\hline
\end{tabular}

\subsection{Hedonik fiyat fonksiyonları}

ODTÜ Ormanı manzarasının varlığı (MNORM), orman görüntüsünün boyutu (ORGÖR) ve kalitesi- ne (ORKLT) ilişkin nitel değişkenler kullanılarak üretilen üç HF fonksiyonu Tablo 2'de verilmiştir. Bu tabloda yer alan her üç fonksiyon da \%99 güven düzeyinde anlamlıdır; konut satış fiyatlarının \%76- 
82'sini yansıtmaktadır. Tüm bağımsız değişkenlerin katsayılarının işaretleri beklentilere uygundur ve ODTÜ Ormanı manzarası niteliğini yansıtan tüm değişkenler en az \%95 güven düzeyinde anlamlıdır. Ayrıca diğer değişkenlerin de büyük bölümünün istatistiksel olarak anlamlı olduğu görülmektedir.

ODTÜ Ormanı manzarası için nicel değişkenlerle
(ORUZAK, ORALAN) üç HF fonksiyonu türetilmiştir (Tablo 3). IV. fonksiyonda doğrudan ORUZAK, V. fonksiyonda ORALAN değişkenleri kullanılırken, VI. fonksiyonda orman manzarasının estetik güzelliğinin hem uzaklık hem de kapsanan alan açısından farklılaşabileceği düşüncesiyle iki değişken birlikte yer almıştır.

Tablo 2. Nitel orman manzarası değişkenleriyle hedonik fiyat fonksiyonları Table 2. Hedonic price functions with qualitative forest view variables

\begin{tabular}{|c|c|c|c|c|c|c|}
\hline \multirow[b]{2}{*}{ Değişkenler } & \multicolumn{2}{|c|}{ I } & \multicolumn{2}{|c|}{ II } & \multicolumn{2}{|c|}{ III } \\
\hline & Katsay 1 & t değeri & Katsay 1 & t değeri & Katsay 1 & t değeri \\
\hline Sabit & $11,347 * * *$ & 171,825 & $11,462 * * *$ & 236,017 & $11,460 * * *$ & 236,695 \\
\hline ALAN & $0,002 * * *$ & 4,251 & $0,002 * * *$ & 3,693 & $0,001 * * *$ & 3,568 \\
\hline ODASY & $0,058 * *$ & 2,126 & $0,088 * * *$ & 3,719 & $0,090 * * *$ & 3,791 \\
\hline KATOR & $0,150 * * *$ & 3,601 & $0,160 * * *$ & 4,473 & $0,160 * * *$ & 4,500 \\
\hline SİTE & & & $0,130 * * *$ & 3,803 & $0,126 * * *$ & 3,699 \\
\hline MUTF1 & & & $0,206^{* * *}$ & 6,361 & $0,205 * * *$ & 6,365 \\
\hline MUTF2 & $0,365 * * *$ & 5,604 & & & & \\
\hline BANYO & $0,224 * * *$ & 6,386 & $0,172 * * *$ & 5,608 & $0,173 * * *$ & 5,651 \\
\hline GDOLAP & $0,149 * * *$ & 4,489 & & & & \\
\hline BALKON & $0,056^{*}$ & 1,794 & & & & \\
\hline DEKOR & $0,237 * *$ & 2,260 & & & & \\
\hline PKAPI & $0,123 * * *$ & 3,854 & & & & \\
\hline SZEMIN & 0,051 & 1,320 & & & & \\
\hline KONMER & & & $0,272 * * *$ & 4,660 & $0,271 * * *$ & 4,685 \\
\hline \multicolumn{7}{|l|}{ OTPARK } \\
\hline ORAN & $0,303 * * *$ & 4,787 & $0,199 * * *$ & 3,187 & $0,190 * * *$ & 3,024 \\
\hline \multicolumn{7}{|l|}{ DOGU } \\
\hline CADDE & $0,148 * * *$ & 3,803 & $0,108 * * *$ & 3,220 & $0,109 * * *$ & 3,250 \\
\hline MNPARK & $0,151 * * *$ & 3,366 & $0,095^{* *}$ & 2,380 & $0,093 * *$ & 2,345 \\
\hline MNGÖL & & & $0,314 * * *$ & 3,799 & $0,311 * * *$ & 3,764 \\
\hline MNORM & $0,067 * *$ & 1,968 & & & & \\
\hline ORGÖR & & & $0,020 * *$ & 2,218 & & \\
\hline ORKLT & & & & & $0,020 * *$ & 2,516 \\
\hline Bağımlı Değişken & \multicolumn{6}{|c|}{ LN (STFYTE) } \\
\hline Gözlem sayısı & \multicolumn{2}{|c|}{296} & \multicolumn{2}{|c|}{296} & \multicolumn{2}{|c|}{296} \\
\hline F-test & \multicolumn{2}{|c|}{$68,903 * * *$} & \multicolumn{2}{|c|}{$114,454 * * *$} & \multicolumn{2}{|c|}{$115,130 * * *$} \\
\hline $\mathrm{R}^{2}$ & \multicolumn{2}{|c|}{0,774} & \multicolumn{2}{|c|}{0,829} & \multicolumn{2}{|c|}{0,830} \\
\hline Düzeltilmiş R² & \multicolumn{2}{|c|}{0,763} & \multicolumn{2}{|c|}{0,822} & \multicolumn{2}{|c|}{0,823} \\
\hline
\end{tabular}

$\mathrm{Bu} \mathrm{HF}$ fonksiyonları da \%99 güven düzeyinde anlamlıdır ve tüm bağımsız değişkenlerin katsayı işaretleri beklentilere uygundur. IV. ve VI. fonksiyonlar konut satıș fiyatlarının \%85'ini, V. fonksiyon \%83'ünü yansıtmaktadır. Üç fonksiyonda da ODTÜ Ormanı manzarası niteliğini yansıtan tüm değişkenler en az \%90 güven düzeyinde anlamlıdır ve diğer değişkenlerin büyük bölümünün istatistik- sel olarak anlamlı olduğu görülmektedir.

Beklentilere uygun olarak ORUZAK değişkeninin işareti negatif, ORALAN değişkeninin ise pozitiftir. IV. fonksiyon ODTÜ Ormanından her bir metre uzaklaştıkça konut fiyatının \%0,0097 azaldığını, V. fonksiyon ise manzarada kapsanan orman alanındaki her bir hektarlık artış karşısında konut fiyatının \%0,035 arttığını göstermektedir. 


\subsection{Ekonomik değer tahminleri}

Yarı logaritmik model için her bir bağımsız değişkenin katsayısının konut fiyatı ile çarpımı, ilgili niteliğin bir biriminin marjinal örtük fiyatını vermektedir. Buna göre niteliklerin her bir birimi için ortalama konut fiyatına göre örtük fiyatlar Tablo 4’ün beşinci sütununda hesaplanmıştır.
ODTÜ Ormanı manzarasının farklı ölçütlere göre tahmin edilen marjinal örtük fiyatları, orman varlığının konut fiyatlarına ortalama 19.288,72 TL, konut manzarasında orman görüntüsünün boyutunun her bir seviyesinin 5.825,76 TL, orman manzaras1 kalitesinin her bir seviyesinin 5.774,43 TL katk1s1 olduğunu göstermektedir. Bununla birlikte orman manzarasına her bir $1 \mathrm{~m}$ 'lik yakınlık konut fiyatla-

Tablo 3. Nicel orman manzarası değișkenleriyle hedonik fiyat fonksiyonları Table 3. Hedonic price functions with quantitative forest view variables

\begin{tabular}{|c|c|c|c|c|c|c|}
\hline \multirow[b]{2}{*}{ Değişkenler } & \multicolumn{2}{|l|}{ IV } & \multicolumn{2}{|l|}{$\mathrm{V}$} & \multicolumn{2}{|l|}{ VI } \\
\hline & Katsay1 & $\mathrm{t}$ değeri & Katsay1 & t değeri & Katsay1 & t değeri \\
\hline Sabit & $11,584 * * *$ & 191,843 & $11,505^{* * *}$ & 243,504 & $11,580^{* * *}$ & 192,953 \\
\hline ALAN & $0,001 * * *$ & 3,275 & $0,001 * * *$ & 3,670 & $0,001 * * *$ & 3,418 \\
\hline ODASY & $0,081 * * *$ & 3,120 & $0,083^{* * *}$ & 3,627 & $0,080^{* * *}$ & 3,133 \\
\hline KATOR & $0,144 * * *$ & 3,170 & $0,176^{* * *}$ & 5,119 & $0,148 * * *$ & 3,267 \\
\hline SİTE & $0,119 * * *$ & 2,865 & $0,113 * * *$ & 3,353 & $0,124 * * *$ & 3,018 \\
\hline MUTF1 & $0,171 * * *$ & 4,735 & $0,203 * * *$ & 6,438 & $0,163^{* * *}$ & 4,502 \\
\hline BANYO & $0,210 * * *$ & 5,658 & $0,164 * * *$ & 5,472 & $0,201 * * *$ & 5,414 \\
\hline KONMER & $0,269 * * *$ & 4,509 & $0,249 * * *$ & 4,345 & $0,252 * * *$ & 4,196 \\
\hline OTPARK & $0,092 * * *$ & 2,743 & $0,106 * * *$ & 3,555 & $0,081 * * *$ & 2,383 \\
\hline ORAN & $0,185^{* * *}$ & 2,725 & $0,157 * *$ & 2,289 & 0,123 & 1,627 \\
\hline DOGU & $-0,168 * * *$ & $-2,702$ & $-0,089^{* *}$ & $-2,258$ & $-0,165^{* * *}$ & $-2,660$ \\
\hline CADDE & 0,056 & 1,404 & $0,079 * *$ & 2,388 & 0,046 & 1,170 \\
\hline MNPARK & $0,139 * * *$ & 2,868 & $0,085^{* *}$ & 2,167 & $0,127 * * *$ & 2,611 \\
\hline MNGOL & $0,349 * * *$ & 4,327 & $0,264 * * *$ & 2,970 & $0,283^{* * *}$ & 3,214 \\
\hline ORUZAK & $-0,000097 * * *$ & $-2,796$ & & & $-0,000094 * * *$ & $-2,743$ \\
\hline ORALAN & & & $0,00035^{*}$ & 1,766 & $0,000366^{*}$ & 1,850 \\
\hline Bağımlı Değişken & \multicolumn{6}{|c|}{ LN (STFYTE) } \\
\hline Gözlem sayısı & \multicolumn{2}{|l|}{198} & \multicolumn{2}{|c|}{296} & \multicolumn{2}{|l|}{198} \\
\hline F-test & \multicolumn{2}{|l|}{$78,817 * * *$} & \multicolumn{2}{|c|}{$105,646^{* * *}$} & \multicolumn{2}{|l|}{$74,765 * * *$} \\
\hline $\mathrm{R}^{2}$ & \multicolumn{2}{|l|}{0,858} & \multicolumn{2}{|c|}{0,840} & \multicolumn{2}{|l|}{0,860} \\
\hline Düzeltilmiş R² & \multicolumn{2}{|l|}{0,847} & \multicolumn{2}{|c|}{0,832} & \multicolumn{2}{|l|}{0,849} \\
\hline
\end{tabular}

rında 31,68 TL pozitif katkı sağlamaktadır. Orman manzarasında her bir hektarlık artış ise konut fiyatını 101,70 TL artırmaktadır.

Farklı orman manzarası niteliklerine göre ODTÜ Ormanı manzarasının konut başına değeri, marjinal fiyatlar ve ODTÜ Ormanı manzarasına sahip konutlar için niteliklerin ortalama değerleri (Tablo 1) kullanılarak Tablo 4'ün altıncı sütununda hesaplanmıştır. ODTÜ Ormanı manzarası için MNORM, ORGÖR ve ORKLT gibi nitel ölçütlere dayanan değişkenler konut başına 15.535 TL ile 19.289 TL arasında ekonomik değer tahminleri üretmiştir.

Nicel ölçütlerden ORUZAK değișkeni, nitel değişkenlerle belirlenen değer aralığ 1 içinde 16.821 TL'lik konut başına orman manzarası değeri sağ- larken, konut manzarasında yer alan orman alanı büyüklüğüne bağlı ORALAN değişkeni diğerlerine göre oldukça düşük değer tahmini (5.872 TL) üretmiştir. Orman manzarasının konut fiyatlarına etkisinin hem uzaklık hem de orman alanı büyüklüğüne bağlı olduğu düșüncesiyle türetilen HF fonksiyonuna göre ise diğer değer tahminlerinin üzerinde konut başına 23.315 TL'lik bir ekonomik değer büyüklüğüne ulaşılmıştır.

$\mathrm{Bu}$ değer tahminlerine göre, orman manzarasının konut fiyatlarına katkısı, tablodaki değişkenlerin verildiği sirayla, $\% 6,68, \% 5,38, \% 6,33, \% 5,14$, $\% 2,03$ ve $\% 7,13$ olarak ortaya çıkmaktadır. Uzaklıkla kapsanan orman alanının artması, manzara değeri arasındaki ters ilişki ORALAN değişkeninin tek başına kullanılamayacağını gösterdiğinden 
Tablo 4. ODTÜ Ormanı manzarası için ekonomik değer tahminleri Table 4. Economic value estimates for the METU Forest view

\begin{tabular}{|c|c|c|c|c|c|c|c|}
\hline \multirow{3}{*}{ 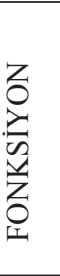 } & \multirow{3}{*}{$\begin{array}{c}\text { Nitelik } \\
\text { Değişkeni }\end{array}$} & \multirow{3}{*}{ Katsayıs1 } & \multirow[b]{2}{*}{$\begin{array}{l}\text { Ort. Konut } \\
\text { Fiyat1 }\end{array}$} & \multirow[b]{2}{*}{$\begin{array}{l}\text { Marjinal } \\
\text { örtük } \\
\text { fiyatı }\end{array}$} & \multicolumn{3}{|c|}{ ODTÜ Ormanı Manzara Değeri } \\
\hline & & & & & $\begin{array}{l}\text { Konut } \\
\text { başına }\end{array}$ & Y1ll1k & $\begin{array}{l}\text { Hedef } \\
\text { Konut } \\
\text { Pazar1 }\end{array}$ \\
\hline & & & $\mathrm{TL}$ & $\mathrm{TL}$ & $\mathrm{TL}$ & $\begin{array}{c}\text { Milyon } \\
\text { TL/y1l }\end{array}$ & $\begin{array}{c}\text { Milyon } \\
\text { TL }\end{array}$ \\
\hline$(1)$ & $(2)$ & (3) & (4) & $(5)$ & $(6)$ & $(7)$ & $(8)$ \\
\hline $\mathrm{I}$ & MNORM & 0,0668 & $288.877,26$ & $19.288,72$ & $19.288,72$ & 10,01 & 124,99 \\
\hline II & ORGÖR & 0,0202 & $288.877,26$ & $5.825,76$ & $15.535,35$ & 8,06 & 100,67 \\
\hline III & ORKLT & 0,0200 & $288.877,26$ & $5.774,43$ & $18.285,71$ & 9,49 & 118,49 \\
\hline IV & ORUZAK & $-9,7.10^{-5}$ & $327.135,64$ & 31,68 & $16.821,36$ & 8,73 & 109,00 \\
\hline $\mathrm{V}$ & ORALAN & 0,00035 & $288.877,26$ & 101,70 & $5.872,28$ & 3,05 & 38,05 \\
\hline \multirow[t]{2}{*}{ VI } & ORUZAK & $-9,4 \cdot 10^{-5}$ & $327.135,64$ & 30,89 & \multirow{2}{*}{$23.315,29$} & \multirow{2}{*}{12,10} & \multirow{2}{*}{151,08} \\
\hline & ORALAN & 0,00037 & $327.135,64$ & 119,67 & & & \\
\hline
\end{tabular}

V. HF fonksiyonu ile türetilen değerler değerlendirmeden dışlanmıştır.

Tablonun yedinci sütununda orman manzarasına sahip konutlar için niteliklerin ortalama değerleri, hedef konut pazarında yıllık konut satış sayısı ve orman manzarasını görme oranı kullanılarak ODTÜ Ormanı manzarasının yıllık değeri hesaplanmıştır. ORALAN değişkenini içeren fonksiyon dışındaki diğer fonksiyonlarla orman manzarası için 8,06 ile 12,10 milyon TL arasında y1llık estetik değer tahminlerine ulaşılmaktadır. Bu değerler, ODTÜ Ormanının hedef konut pazarının manzarasinı oluşturan bölümünün yıllık olarak hektarda en az 7.112-10.673 TL arasında estetik fayda yarattığın1 göstermektedir.

Tablonun son sütununda ise ODTÜ Ormanı manzarasının hedef konut pazarı için konut satış fiyatları üzerinden yarattığı toplam değer, niteliklerin marjinal örtük fiyatları, niteliklerin orman manzarasına sahip konutlar için ortalama değerleri ve hedef konut pazarında ODTÜ Ormanı manzarasına sahip konut sayısı dikkate alınarak hesaplanmıştır. $\mathrm{Bu}$ şekilde çalışma yıllarındaki pazar koşulları altında hedef konut pazarı için orman manzarasının değeri olarak farklı fonksiyonlara göre 101 ile 151 milyon TL arasında toplam değer hesaplanmıştır. Kuşkusuz bu toplam değer hesabında konut stokundaki genişlemeler, gelecekteki satışlar için paranın zaman değeri ve hedef konut pazarı dışındaki konutlar ve işyerleri dikkate alınmamıștır.

\section{Tartışma ve Sonuç}

Regresyon analizi sonuçları kullanılan manzara nitelikleri için ODTÜ Ormanı manzarasının konut fiyatları üzerindeki etkisinin anlamlı olduğunu, dolayısıyla yöntem bölümünde sunulan $\mathrm{H}_{1}$ hipotezi- nin kullanılan manzara nitelikleri için kabul edildiği anlamına gelmektedir. Araştırmada hedef konut pazarında ODTÜ Ormanı manzarasının estetik faydaları için nicel ve nitel değişkenlerle türetilen HF fonksiyonlarıyla, konut başına 15.535-23.315 TL arasında ekonomik değer tahminleri üretilmiştir. Bu değerler, araştırma örneklemindeki ortalama konut fiyatları dikkate alındığında orman manzarası etkisinin \%5,14-7,13 arasında olduğunu göstermektedir. Bu değer tahminleri, kent ormanları için Finlandiya'da gerçekleştirilen bir araştırmada (Tyrvainen ve Miettinen, 2000) elde edilen değer tahminleri ile örtüşmektedir.

Araştırma, ODTÜ Ormanı manzarasının, farklı orman manzarası nitelikleri için yıllık 8,06-12,10 milyon TL, hektarda 7.112-10.673 TL arasında estetik fayda yarattığını göstermiştir. Birim alan için degerler, ormanın karbon tutma faydasından (26 TL/ ha/yıl) ve her ne kadar ODTÜ Ormanı için öncelikli işlevler arasında olmasa da Türkiye'de odun hammaddesi üretiminin ortalama değerinden (184 TL/ ha/yıl) oldukça yüksektir. Örneklemdeki konutların kapsadığı orman manzarasının amenajman palanında sadece \%3,3'ünün estetik işleve tahsis edildiği düșünüldüğünde, bu değerler, kentlerde ormanların diğer işlevlerle karşılaştırmak koşuluyla öncelikli işlev olarak estetik işleve tahsis edilebileceğini göstermektedir.

Toplam ekonomik değer çerçevesi içinde yapılan çalışmalarda Türkiye'de orman kaynaklarının toplumsal refaha pozitif katkıları, ortak noktaları çok olan farklı çalışmalarda 54,18 \$/ha (Bann ve Clemens, 1999), 49,3 \$/ha (Türker ve ark., 2005) ve $78,5 \$$ /ha (Pak ve ark., 2010) olarak hesaplanmıştır. ODTÜ Ormanı manzarası için üretilen birim alan değerlerinin, estetik hizmetleri içermeyen ulusal düzeydeki bu ortalama değer tahminlerinin oldukça 
üstünde olması, ormanların ișlevsel tahsisi açısından yukarıdaki öneriyi desteklemektedir. Ayrıca bu tür çevresel değer belirleme araştırmalarında kullanılan maliyete dayalı yöntemlerin zaaflarını ve mekânsal düzeyde çalışmanın önemini göstermiştir.

Belki de en önemlisi, ODTÜ Ormanı manzarası için elde edilen değer tahminleri, yasal olarak kent ormanı statüsünde görülmeyen ODTÜ Ormanının Konijnendijk (2003)'in kriterlerine ilaveten, Kuchelmeister (2000)'in fayda sinıflandırmasına göre de işlevsel olarak kent ormanı olduğunu kanıtlamaktadır. Bu doğrultuda yasal düzenlemelerin yapılması gerekmektedir.

ODTÜ Ormanı manzarasının hedef konut pazarı için toplam değerinin, farklı manzara niteliklerine göre 101 ile 151 milyon TL arasında olduğu belirlenmiştir. Bu değer, hektarda 88.802-133.273 TL arasında manzara değeri olduğunu göstermektedir.

Ormanın estetik faydalarının konut pazarında nakde dönüşmesi, konut pazarında bir katma değer yaratmakla kalmayıp, Devletin vergi gelirlerini de artırmaktadır. Ankara Büyükşehir Belediyesi s1nırlarında yıllık emlak vergisi tutarının konut değerinin \%o2'si olduğu dikkate alındığında ODTÜ Ormanı manzarasının hedef konut pazarında her yıl 202.000-302.000 TL arasında vergi gelirlerini artırdığı anlaşılmaktadır.

"Ormana uzaklık” değişkeni ile türetilen HF fonksiyonuna göre, diğer tüm nitelikleri aynı olan iki konuttan ormana $1 \mathrm{~km}$ daha yakın olan konutun değeri yaklaşık 31.680 TL daha fazla olmaktadır. Literatüre benzer şekilde ormana uzaklık arttıkça manzaranın değerinin düştüğünü gösteren bu bilgi, kent ormanlarının kentsel yerleşimlerin içinde veya manzarasından faydalanılacak kadar yakın olmasının da önemini kanıtlamaktadır.

Çalışmada HFY ile türetilen HF fonksiyonları içinde orman manzarası niteliklerinin anlamlı olarak yer alması ve bu fonksiyonlarla üretilen değer tahminleri, ODTÜ Ormanı manzarasının konutlar için arzu edilen bir nitelik olduğunu ve estetik faydalarının konut fiyatlarına yansıdığını göstermiştir. Diğer yandan elde edilen değer tahminlerinin, ormanın faydalarından sadece birine ait olduğu, konut stokundaki genişlemeleri, hedef konut pazarına dahil edilmeyen kamu yapıları, konutlar ve işyerlerinin, konutlarda ikamet edenler dişında çevrede seyahat edenler ve yürüyüş gibi rekreasyon etkinlikleri gerçekleştirenlerin ODTÜ Ormanından elde ettiği estetik faydaları içermediği karar verme süreçlerinde, özellikle diğer sektörlerle karşılaştırmalarda dikkate alınmalıdır. Ayrıca ODTÜ Ormanı meşcerelerinin gelişimi, hedef konut pazarında ODTÜ Ormanı manzarasına girmeyen meşcerelerin de orman bütünlüğünü sağlamaları nedeniyle estetik faydalara katkısı ve toplam değer hesabında paranın zaman değerinin dikkate alınmadığı göz önünde tutulmalidir.

ODTÜ Ormanının dıșsallıklarından biri olan estetik hizmetlerin içselleştirilmesi için faydalanıcılar tarafindan doğrudan veya dolaylı olarak finanse edilmesi gerekmektedir. Bu doğrultuda araç olarak düşünülebilecek belediye vergi gelirleri ve tapu harçlarından pay ayrılmasında bu araştırma ile elde edilen değer tahminleri ve oranlar kullanılabilir. Crompton (2005), New York'ta Central Park'ın emlak vergilerinde yarattığı artışla finanse edildiği, parkın harcamaları çıkarıldığında bu şekilde yıllık 4,4 milyon \$ net gelir yarattığını ifade etmektedir. $\mathrm{Bu}$ finansman araçları, son yıllarda gündemde olan ekosistem hizmetleri için ödemeler olgusu bağlamında özel ormancılığı teşvik edebilir.

Mahalle parklarının varlığının tüm HF fonksiyonlarında orman manzarasına ilişkin değişkenlere göre daha büyük katsayılar elde etmesi, diğer yeşil alanların önemi göstermektedir. Ayrıca çocuk parklarının fonksiyonlara anlamlı olarak girememesi, manzara dışındaki işlevlerden kaynaklanabilir ve daha yeşil mahalle parklarına ihtiyaç duyulduğu anlamına gelebilir.

Araştırmada HF fonksiyonlarında ODTÜ Ormanı manzarası için kullanılan nitel değişkenler arasında "orman manzarasının varlığı" değişkeni, en pratik ve bireysel olarak kullanıldığında en yüksek değeri üretirken, "orman manzarasının görüntüsü ve kalitesine" ilişkin değişkenlerin daha güvenilir olduklar1 görülmüştür. Ancak orman manzarasının kalitesi değişkeni, veri toplama yöntemi açısından HFY'nin temel varsayımlarına aykırı olmakla birlikte, zaman alıcı ve maliyeti daha yüksektir.

HF fonksiyonlarında ODTÜ Ormanı manzarası için kullanılan tüm değişkenler karşılaştırıldığında, nicel değişkenlerin güvenilirlik açısından ön planda olduğu görülmektedir. "Ormana uzaklık” değişkeni, daha güvenilir değer tahminleri üretmiştir ve CBS yazılımları ile kolaylıkla üretilebilmektedir. "Konut manzarasının kapsadığı orman alanı" değişkeninin tek başına kullanıldığında güvenilirliği daha az ve düşük değer tahminleri üretmesi Morancho (2003)'nun sonuçlarıyla paraleldir. Bununla birlikte, ormana uzaklık değişkeni ile birlikte kullanıldığında en yüksek değer tahmini yanında, istatistiksel olarak en anlamlı HF fonksiyonunun üretilmesi bu iki değişkenin konut manzarasının estetik güzelliği için tamamlayıcı olduklarını göstermektedir.

Konut manzarasında orman görüntüsünün boyutu ve kapsanan orman alanı büyüklüğüne ilişkin verilerin iki boyutlu görsellerden elde edilmesi zaman alıcı ve güçken, üç boyutlu haritaların varlığı halinde CBS yazılımları yardımıyla pratik olarak 
üretilebilir. Ayrıca uzaklık kategorilerinin ve orman manzarasında yer alan meşcerelerin ağaç türü bileşimleri, gelişim çağları ve kapalılıklarının konut fiyatlarına etkisini göstermek için otokorelasyon probleminden sakınarak farklı ekonometrik analiz teknikleri ile araştırmalara ihtiyaç duyulmaktadır.

$\mathrm{Bu}$ araştırma, yöntembilim açısından kent ormanlarına yönelik ülkemizde gerçekleştirilen ilk çalışma olmakla birlikte, kentsel yeşil alanlarla ilgili bazı HF araştırmalarının aksine, tek bağımsız değişkene bağlı yanılgılı tahminlere yol açmayacak şekilde, farklı orman ve diğer yeşil alan manzarası dahil, birçok konut niteliğini değişken olarak dikkate alan HF fonksiyonları ve değer tahminleri üretmiştir. Araştırma ile elde edilen değer tahminleri, kent ormanlarının estetik faydalarına ilişkin bir gösterge sağlamakla birlikte, kent ormanlarının yarattığı estetik faydaların büyüklüğünü kanıtlayarak, orman kaynakları yönetim politika, plan, program ve projelerine estetik faydalarla ilgili parametrelerin eklenmesinin önemini göstermiş ve fayda mukayesesine, dolayısıyla fayda maliyet analizlerine imkân sağlamıştır. Elde edilen değer tahminleri ayrica toplam orman değeri hesapları ve kaynak muhasebesi sistemlerinde de kullanılabilir.

Gelecek araştırmalarda literatürdeki gelişmelere paralel olarak ormanların manzara güzelliği için psiko-fiziksel yaklaşımların kullanılması, uydu görüntüleri ve CBS yazılımları ile parlaklık, gölgelik ve renk analizlerinin yapılması, böylece daha nicel, objektif ve pratik değişkenler türetilmesi Türkiye'de HFY araştırmalarının gelişimine katkıda bulunacaktır. Türkiye'de konut niteliklerine ilişkin güvenilir veri tabanları geliştikçe, emlak şirketleri ve diğer kaynaklardan elde edilen konut niteliklerine ait bilgilerin anket gibi zaman alıcı ve maliyeti yüksek bir teknikle denetlenmesine ihtiyaç duyulmadan, CBS teknolojilerini kullanarak orman manzarasının değeri için hızlı ve etkin hedonik analizler gerçekleştirmek mümkün olacaktır.

Not: Bu makale, 2011-2013 yillarinda T.C. Orman ve Su Issleri Bakanlığl, Orman Genel Müdürlüğü, İç Anadolu Ormancılık Araştırma Enstitüsü Müdürlüğünce "Kent Ormanlarının Estetik Değerinin Tahmin Edilmesi: ODTÜ Ormanı Örneğì" başlığlyla gerçekleştirilen araştırma sonucunda hazırlanan ve OGM Araştırma İhtisas Grupları Toplantısında yayınlanması yönünde karar verilen Proje Sonuç Raporunun (Kaya ve Özyürek, 2013) özetidir.

\section{Kaynaklar}

Abayhan, A. D., Çubukçu, K. M., 2010. Manzara sahipliliğinin konut fiyatına etkisinin hedonik fiyat yöntemi ile modellenmesi: İzmir Yedigöller Rekreasyon Alanı çevresine ilişkin ampirik çalışma. 13. Ulusal Bölge BilimilBölge Planlama Kongresi: Bölgesel Gelişme İçin Yapılanma Gündemi. Bildiri Özetleri, s. 65, 11-12 Mart 2010, Yıldız Teknik
Üniversitesi, İstanbul.

Ahamada, I., Flachaire, E., Lubat, M., 2008. Prix des logements et autocorrélation spatiale: une approche semi-paramétrique. Economie Publique 20: 131-145.

Alkay, E., 2002. Hedonik fiyat yöntemi ile kentsel yeșil alanların ekonomik değerlerinin ölçülmesi. İstanbul Teknik Üniversitesi Fen Bilimleri Enstitüsü, Yüksek Lisans Tezi, İstanbul.

Altunkasa, M. F., Uslu, C., 2004. The effects of urban green spaces on house prices in the upper northwest urban development area of Adana (Turkey). Turkish Journal of Agriculture and Forestry 28 (2004): 203-209.

Anderson, L., Cordell, H., 1988. Influence of trees on residential property values in Athens, Georgia (USA): A survey based on actual sales price. Landscape and Urban Planning 15: $153-164$.

AOİM, 2006. Orta Doğu Teknik Üniversitesi Tüzel Kisilik Ormanı Fonksiyonel Orman Amenajman Planı I. Yenileme (2007-2026), Ankara.

Baldemir, E., Kesbiç, C. Y., İnci, M., 2008. Estimating hedonic demand parameters in real estate market: The case of Muğla. Muğla Üniversitesi Sosyal Bilimler Enstitüsü Dergisi 20: 41-66.

Bann, C., Clemens, M., 1999. Ormanc1lık Sektör İncelemesi Küresel Örtüşme Programı Çalışması Final Raporu, İksir Yayınevi, Ankara.

Benson, E. D., Hansen, J. L., Schwartz Jr., A. L., 2000. Water views and residential property values. Appraisal Journal 68(3): 260-271.

Boyacıgil, O., 2003. Hedonic pricing yönteminin İskenderun kenti örneğinde uygulanması. Çukurova Üniversitesi Fen Bilimleri Enstitüsü, Yüksek Lisans Tezi, Adana.

Choumert, J., Travers, M., Delaître, C., Beaujouan, V., 2009. Capitalization of green spaces into housing values in the city of Angers: A hedonic approach. First International Conference on Landscape Economics, July 2-4, Vienna.

Correll, M. R., Lillydahl, J. H., Singell. L. D., 1978. The effects of greenbelts on residential property values: Some findings on the political economy of open space. Land Economics 54(2): 207-17.

Crompton, J. L., 2005. The impact of parks on property values: empirical evidence from the past two decades in the United States. Managing Leisure 10 (October 2005): 203215.

Çetintahra, G. E., Çubukçu, E., 2011. Çevre estetiğinin konut fiyatlarına etkisi. ITTÜ Dergisi A: Mimarlık, Planlama, Tasarim 10(1): 3-12.

Dehring, C., Dunse, N., 2006. Housing density and the effect of proximity to public open space in Aberdeen, Scotland. Real Estate Economics 34: 553-566.

Dombrow, J. M. R., Sirmans, C. F., 2000. The market value of mature trees in single family housing markets. The Appraisal Journal 68: 39-43.

Donovan, G.H., Butry, D.T., 2010. Trees in the city: valuing street trees in Portland, Oregon. Landscape and Urban Planning 94(2): 77-83.

Eğdemir, G., 2001. İstanbul'da konut fiyatlarının mekânsal analizi. İstanbul Teknik Üniversitesi Fen Bilimleri Enstitüsü, Doktora Tezi, İstanbul.

Hammer, T. R., Coughlin, R. E., Horn, E. T., 1974. The Effect of a Large Park on Real Estate Value. Journal of the American Institute of Planners 40: 274-277.

Hanley, N. and C. Spash, 1993. Cost-Benefit Analysis and the Environment. Edward Elgar Publication Ltd., Aldershot. 
Kaya, G., 2010. Türkiye'de çevresel değer belirleme araştırmaları, darboğazlar ve öneriler. Ekoloji 2010 Sempozyumu, 5-7 Mayis 2010, Aksaray.

Konijnendijk, C., 2003. A decade of urban forestry in Europe. Forest Policy and Economics 5:173-186.

Kuchelmeister, G., 2000. Trees for the urban millennium: urban forestry update. Unasylva 200(51): 49-55.

Lothian, A., 2010. Pricing Landscape Quality: The Influence of Landscape Views on House Values. http://www.scenicsolutions.com.au/Attached.PDFs/Pricing\%201s\%20quality.pdf (Ziyaret Tarihi: 13.01.2013).

Mansfield, C., Pattanayak, K. S., McDow, W., McDonald, R., Halpin, H., 2005. Shades of green: Measuring the value of urban forests in the housing market. Journal of Forest Economics 11: 177-199.

Melichar, J., Vojacek, O., Rieger, P., Jedlicka, K., 2009. Measuring the value of urban forest using the hedonic price approach. Czech Regional Studies 3(2): 13-20.

Mesire Yerleri Yönetmeliği, 2013. TC Resmi Gazete, 28578, 5 Mart 2013.

Mendelsohn, R., Markström, D., 1988. The use of travel cost and hedonic methods in assessing environmental benefits. In: Peterson, G. L., Driver, B. L., Gregory, R. (Eds.), Amenity Resource Valuation: Integrating Economics with Other Disciplines, Venture Publishing Inc., State College, PA., pp. 159-166.

Miller, R.W., 1997. Urban Forestry: Planning and Managing Urban Green Spaces. 2nd ed., Prentice Hall, Englewood Cliffs, NJ.

Morales, D. J., Micha, F. R., Weber, R. L., 1983. Two methods of valuating trees on residential sites. Journal of Arboriculture 9:21-24.

Morancho, A. B., 2003. A hedonic valuation of urban green areas. Landscape and Urban Planning 66(1): 5-41.

More, T. A., Stevens, T. H., Allen, P. G., 1988. Valuation of urban parks. Landscape and Urban Planning 15: 139-152.

Netusil, N. R., 2005. The effect of environmental zoning and amenities on property values: Portland, Oregon. Land Economics 81: 227-246.

ODTÜ, 2015. ODTÜ Ormanı Tarihcesi. http://acdm.metu. edu.tr/tarihce (Ziyaret Tarihi: 24.04.2015).

OGM, 2015. Ormancilik İstatistikleri 2014. http://www. ogm.gov.tr/ekutuphane/Sayfalar/Istatistikler.aspx (Ziyaret Tarihi: 03.07.2015)

Pak, M., Türker, M. F., Öztürk, A. (2010) Total economic value of forest resources in Turkey. African Journal of Agricultural Research 5(15): 1908-1916.

Pearson, L, 2002. The impact of Noosa national park on surrounding property values: an application of the hedonic price method. Economic Analysis and Policy 32(2):155-170.

Rosen, S., 1974. Hedonic prices and 1mplicit markets. Journal of Political Economy 82: 35-55.

Sander, H. A., Polasky, S., Haight, R. G., 2010. The value of urban tree cover: A hedonic property price model in Ramsey and Dakota counties, Minnesota, USA. Ecological Economics 69(8): 1646-1656.

Sielski, D. M., 2002. The impact of parks on residential property values: An analysis of two parks within Washington county, Wisconsin. University of Wisconsin, Master of Urban Planning Program.

Tajima, K., 2003. New estimates of the demand for urban green space: Implications for valuing the environmental benefits of Boston's big dig project. Journal of Urban Affairs 25
(5): 641-655.

Taylor, L. O., 2003. The Hedonic Method. In: Champ, P. A., Boyle, K. J., Brown, T. C. (Eds.), A Primer on Nonmarket Valuation, Kluwer Academic Publishers, Dordrecht, pp. 331394.

TC Merkez Bankas1, 2013a. Haziran-2013 döviz kurları. http://www.tcmb.gov.tr/kurlar/201306/Jun tr.html (Ziyaret Tarihi: 03.10.2013).

TC Merkez Bankası, 2013b. Türkiye konut fiyat endeksi (TKFE) ve düzey 2 endeks değerleri. http://www.tcmb. gov.tr/wps/wcm/connect $/ \mathrm{tcmb}+\mathrm{tr} / \mathrm{tcmb}+\mathrm{tr} / \mathrm{main}+\mathrm{menu} /$ istatistikler/reel+sektor+istatistikleri/konut+fiyat+endeksi/ veri+\%28tablolar\%29 (Ziyaret Tarihi: 03.10.2013).

Tekel, A., Akbarishahabi, L., 2013. Determination of opengreen space's effect on around house prices by means of hedonic price model in example of Ankara/Botanik Park. Gazi University Journal of Science 26(2): 347-360.

Thorsnes, P., 2002. The value of a suburban forest preserve: Estimates from sales of vacant residential building lots. Land Economics 78(3): 426-41.

TÜIK, 2011. Seçilmiş Göstergelerle Ankara 2011. TÜİK Yayınları, Yayın No: 3751, Ankara.

TÜİ, 2013a. İllere ve yıllara göre üçer aylık konut satışları. http://www.tuik.gov.tr (Ziyaret Tarihi: 03.10.2013).

TÜIK, 2013b. Nüfus ve Konut Araştırması 2011, TÜiK Yayınları, Yayın No: 4030, Ankara

TÜİK, 2013c. 07F-İstatistiki Bilgi İsteği konulu resmi yazı. TÜIKK Başkanlığı Bilgi Dağıtım ve İletişim Daire Başkanlığı, 25.10.2013, Say1: 27964695-622.02-7253.

Türker, M. F., Pak, M., Öztürk, A., 2005. Anatolian Peninsula: Turkey, In: Merlo, M., Croitoru, L. (Eds.), Mediterranean Forests and People: the Total Value, Padua University Press, Contagra, pp. 195-212.

Tyrvainen, L., 1997. The Amenity Value of the Urban Forest: An Application of the Hedonic Pricing Method. Landscaping and Urban Planning 37(3-4): 211-222.

Tyrvainen, L., Miettinen, A., 2000. Property prices and urban forest amenities. Journal of Environmental Economics \& Management 39(2): 205-223.

Wang, A.M., 2005. Measuring the benefits of urban green areas: A spatial hedonic approach. The 10th Asian Real Estate Society (AsRES) International Conference, 18-21 July 2005, Sydney, Australia.

Yılmaz, H., Bulut, Z., Temurlenk, M. S., Yeşil, P., 2008. Determination of the impact of parks and playgrounds on house prices in the city of Erzurum, Turkey. International Journal of Natural and Engineering Sciences 2(1): 47-51.

Zhu, P. and Zhang, Y., 2008. Demand for urban forests in United States cities. Landscape and urban Planning 84 (3-4): 293-300 